\title{
Ethical Ideology And Cultural Orientation: Understanding The Individualized Ethical Inclinations Of Marketing Students
}

Brent Smith, Saint Joseph's University, USA

\begin{abstract}
As today's marketing graduates formally enter the business profession, they are expected to demonstrate the fruits of their ethics-intensive education. Hence, their professors and future bosses may call upon these graduates to discern and deal with ethical situations that affect various aspects of company and consumer relations. However, students enter the classroom and business environment with their own individual orientations and ideology that help them determine when an issue is ethical and requires a certain response. Here, I examine the influences of the marketing student's personal cultural orientation and ethical ideology on ethical perception and ethical inclination within the context of two hypothetical marketing/sales scenarios. The findings contribute to the ongoing debate about whether or how much business ethics can really be taught.
\end{abstract}

Keywords: marketing ethics; business education; culture; ethical ideology

\section{INTRODUCTION}

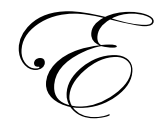

thics has become an integral component of business education. Students in the allied disciplines of management, marketing, accounting, finance, operations, and information systems, have been exposed to professors, textbooks, and cases geared towards helping students navigate the often obscure world of business ethics. The issues are legion, as are the perceptions and evaluations of them. Despite the importance of business ethics to the education and training of marketing students, the focus of this study, the instructional methods for ethical pedagogy seldom take into account the personal backgrounds of today's diverse student cohorts. That is, while instructors and textbook authors may expose students to business case examples where ethical issues presumably exist and/or should be universally discernable, these examples are constructed with inadequately developed conceptions about the personal orientations or ethical ideologies that student actually use to help process them.

Laczniak (1999) finds that marketing is generally considered the most unethically oriented function of business disciplines. Exacerbating future prospects for the discipline are findings that marketing students perceive considerable deficiencies in the level of marketing ethics education in their overall curriculum (Shannon and Berl, 1997). While the Association to Advance Collegiate Schools of Business (AACSB) and leading business schools have responded to the situation by mandating required business ethics courses, shortcomings still exist (Borkowski and Ugras, 1998; Greenman and Sherman, 1999; and others).

As marketing students make the transition from higher education to the business world, they are expected to bring with them better and more explicit ethical training than their counterparts of previous generations. Myriad calls for corporate social responsibility, consumer protection, truth in advertising, transparent access to information, accurate food labeling, and so forth have originated from a diverse cross-section of stakeholders, such as households, governments, consumer advocacy groups, and mainstream media. Formal exposure to these issues cannot guarantee that all students will be necessarily educated in their finer points, particularly where ethics, morality, and social values are concerned. In this light, Desjardins (2003) notes that one should distinguish between 
true ethical values/behaviors and mere conformity to the outwardly tangible signs that are deemed socially acceptable or mandatory. Given the litany list of corporations and business leaders that have been cited by news media for breaches of ethics and public trust, Hartman and Desjardins (2008) underscore the importance of ethical decision making today:

At some point every worker, and certainly everyone in a managerial role, will be faced with an issue that will require ethical decision-making. Not every decision can be covered by economic, legal, or company rules and regulations. More often than not, responsible decision-making must rely on the personal values and principles of the individuals involved. Individuals will have to decide for themselves what type of person they want to be (p. 3-4).

Academic researchers and practitioners in the classroom attest to students' ability to regurgitate facts or give the "right answer" in order to make good impressions or score better grades. Still, given the real importance of ethics within business and society, purposeful ethics oriented pedagogy requires that educators gather some insight about how students individually determine whether, when, and how to respond to ethics intensive issues.

This paper explores how marketing students perceive and evaluate ethical scenarios. It also reflects the notion that business ethics educators can gain practical insights into how students regard and react to such scenarios by learning about their a priori cultural orientations and ethical ideologies. Results from this examination are presented and discussed with implications for marketing educators. Relatively few studies in the area of business ethics education have considered the relationship between personal cultural values and ethics (Bartels, 1967; Cohen, Pant, and Sharp, 1992; Wines and Napier, 1992; Yoo and Donthu, 2002). With the exception of Yoo and Donthu (2002) who were inspired by the work of Vitell, Nwachukwu, and Barnes (1993), most cross-cultural studies of ethics were based on comparison of values reflecting national contexts not individual ones.

Despite the contributions made by these studies, they have been limited in their illumination of how individual level orientations may be associated with personally cultivated ethical values and practices. Hence, the present study advances ethics research and pedagogy by focusing specifically on individual level interplays between culture, ideology, and ethics.

\section{LITERATURE REVIEW AND HYPOTHESES}

Business students, at the undergraduate and graduate levels demonstrate some of the worst attitudes toward cheating, and are likely to bring their poor ethics into their professional careers (McCabe, Butterfield, and Trevino, 2006). Yu and Zhang (2006), in a study of trainee acceptance of corporate wrongdoing, suggest that some businessoriented curricula may "desensitize students to ethical issues and contribute to a moral void in the future corporate leaders" (p. 185). While the AACSB and other educational accrediting bodies have mandated that their members provide business ethics education, the ongoing negative repute of marketers and marketing practices suggests a need to look more carefully at the discipline and its students. Murphy et al. (2005) state that business schools "where professors and students come together to study business theory and practice, are also not immune from criticism. Business Week, Financial Times, and The Wall Street Journal have all leveled charges at business education for teaching short-term financial performance as the main 'gospel' or business success" (p. xvi).

\section{Focus on Marketing Ethics}

Sparks and Hunt (1998) assert that ethics is both personal and learned. Yoo and Donthu (2002) note that learning marketing ethics may occur for marketing students through formal marketing education, business ethics training, and/or actual employment experience. They state further that the "marketing major is expected to have a significant impact on students' marketing ethics because it directly exposes students to the standards in major areas of marketing" (p. 93). Despite the importance of ethics within the marketing discipline and curriculum, most existing studies have evaluated general ethical behavior, not profession-specific ethics (e.g., marketing) (Ford and Richardson, 1994). Yoo and Donthu highlight this issue and potential problems stemming from the failure to realize it, stating: "Marketing people may show more sensitivity to marketing ethics, while accounting people may show more sensitivity to accounting ethics. Thus, the extent that the kind of ethics of interests is relevant to the undergraduate major, the major is expected to have a positive relationship with the ethics" (p. 93). Undergirding the 
call for more focus on marketing ethics for marketing majors, Laczniak (1999) notes the public-at-large has continually held negative perceptions about marketing (e.g., sales, advertising) as the most unethical business function.

Murphy et al. (2005) estimate that between 65 and 75 percent of all managers face major ethical dilemmas, defined as situations where morality does not necessarily render a clearly identifiable, unambiguous choice of action. To this point, Brenkert (2008) suggests that business school professors and students require more than the typical schema of introductions to different ethical theories and lists of moral issues in marketing. This form of applied ethics takes neither professors nor students "into the ethical complexities of the problems marketers face" (Brenkert, 2005, p.8). Robin and Reidenbach (1993) echo this concern declaring that "the direct application of popular moral philosophies such as deontology or utilitarianism to ethical questions in marketing falls short in providing necessary guidance for marketers" (p. 97). These views suggest that formal marketing ethics education is necessary but not sufficient. Why else is it essential to concentrate on marketing ethics? Brenkert (2008) asserts, "Marketing speaks to a large drama in our lives of the conflicts between different sets of values and norms ... to talk about marketing is to address an ongoing ethical conflict" (p. xiii).

\section{Relationship between Ethical Perception and Ethical Inclination}

Contemporary marketing students, like other business students, are trained to apply various duty-based, virtue-based, or consequence-based ethical theories in order to make sense of ethical issues. However, many scenarios have properties, which do not necessarily make their ethicality intuitively discernable to all individuals. Logically speaking, before determining whether a student would favor positive or negative ethical behaviors in a given situation, s/he must first sense or perceive an ethical issue therein. Therefore,

H1. Ethical perceptions are negatively associated with less moral ethical inclinations.

\section{Relationship between Ethical Ideology and Ethical Inclination}

Since ethics is both personal and learned (Sparks and Hunt, 1998), it is important to understand marketing students on an individual basis. Although all marketing students have been exposed to business ethics education through their texts and/or required courses mandated by the AACSB or other accrediting body, it is not safe to assume that all of these students individually champion the same kind of ethical values. Hence, while most students may be exposed to same kind of formal ethics curriculum at business schools or corporate training programs, they can still differ in their approaches to moral perceptions, judgments, and behaviors. Forsyth (1980) contends that individuals possess their own ethical ideologies, which they use to filter and process problem scenarios. These ethical ideologies can be conceptualized according to two dimensions: relativism and idealism. Individuals who espouse an idealistic ideology generally believe that desired outcomes should be achieved without ever causing harm to others. By contrast, individuals who engender a relativistic ideology tend to be more skeptical or dismissive of the idea that moral principles are universal or unconditionally absolute.

As noted by Forsyth (1980), individuals differ in the underlying beliefs that culminate into their ethical ideologies. Consequently, as they observe various situations they may not necessarily notice, perceive, or evaluate them in the same ways and/or to the same ends. Given that ethical breaches, or lapses in sound moral judgment, still occur in the workplace and that ambiguities persist in knowing how to properly interpret ethical situations, ethics officers and professors must effectively comprehend how individuals' ethical inclinations are affected by relativism and idealism.

Individuals who are especially idealistic demonstrate a strict conformity to moral rules and social standards. Reflecting steadfastness in following these rules and standards, idealism increasingly leads an individual towards moral ethical inclination (Forsyth 1980). Hence,

H2. Ethical idealism is negatively associated with less moral ethical inclinations. 
By comparison, individuals who are highly relativistic generally vacillate in their acceptance of rules or standards (Forsyth, 1980). Ultimately, however, they would perceive themselves as exempt from these rules, rejecting the notion that moral rules are actually universal. On a case-by-case basis, they are more focused on whether they relate to the players involved or are directly impacted by particular situations (Forsyth, 1992). Hence, they would demonstrate lesser ethical perceptions and inclinations.

H3. Ethical relativism is positively associated with less moral ethical inclinations.

\section{Relationship between Cultural Orientation and Ethical Inclination}

Culture is a learned system of values that determines how people habitually interpret, perceive, and react to the world around them. Culture provides the context and medium through which people think and express themselves (Hall, 1976). In fact, it has been referred to as the "software of the mind" (Hofstede, 1997). Underscoring this spirit of this metaphoric reference, Hall (1966) emphatically declares:

"No matter how hard man tries, it is impossible for him to divest himself of his own culture, for it has penetrated to the roots of his nervous system and determines how he perceives the world ... people cannot act or interact in any meaningful way except through the medium of culture" (p.177).

Several frameworks of culture have been developed (Hall 1976; Hofstede 1980, 1997; House et al. 2004; Schwartz 1992; and others); however, the most renowned and adopted view can be attributed to Geert Hofstede. Hofstede $(1980,1997)$ developed a five-dimensional model of national culture. The original dimensions included power distance, uncertainty avoidance, individualism v. collectivism, and masculinity. The fifth dimension, known as Confucian dynamism, or long-term orientation, was added later (Hofstede and Bond 1990). While five dimensions exist within Hofstede's framework, these have been heavily debated among cross-cultural scholars, suggesting that power distance and individualism $v$. collectivism are the most consistently accepted and significant dimensions. Given that marketing exchanges (e.g., selling) typically involve asymmetric power, information, and benefits, these two dimensions are relevant and appropriate for the purposes of this study. According to Hofstede, these dimensions of cultural orientation embody the most basic manifestations of culture, which ultimately reflect "broad tendencies to prefer a certain state of affairs over others" (Hofstede 1980, p. 19).

Power distance reflects the extent to which people accept social inequalities. People exhibiting greater power distance values accept uneven differences in power, conform to formal/hierarchical authority, and even tolerate discrimination. With higher power distance, people are also less likely to espouse informal norms and ideals characteristics associated with ethics. Consequently,

H4. Power distance is directly associated with less moral ethical inclinations.

Individualism v. collectivism refers to the balance with which people prioritize the self relative to others, the group, or a community. Individualism reflects a focus on personal or private interests that trump communal ones. Additionally, individualism leads one towards managing very loose relational ties with others. Contrastingly, collectivism signals a concern for closer relational ties, group harmony, shared responsibility, and willingness to contemplate improved connectedness with others. Hui and Triandis (1986) also observed that collectivism is positively associated with sacrifice. Similarly, Schwartz and Bilsky (1987) reveal that collectivists value social stability and individual restraint against practices that may upset the welfare of others. Therefore,

H5. Individualism is negatively associated with ethical inclinations.

Taken together, these hypotheses postulated an individualized context wherein ethical inclination is associated with ethical perception, ethical ideology, and cultural orientation (see Figure 1). 
Figure 1

Diagrammatic Research Model

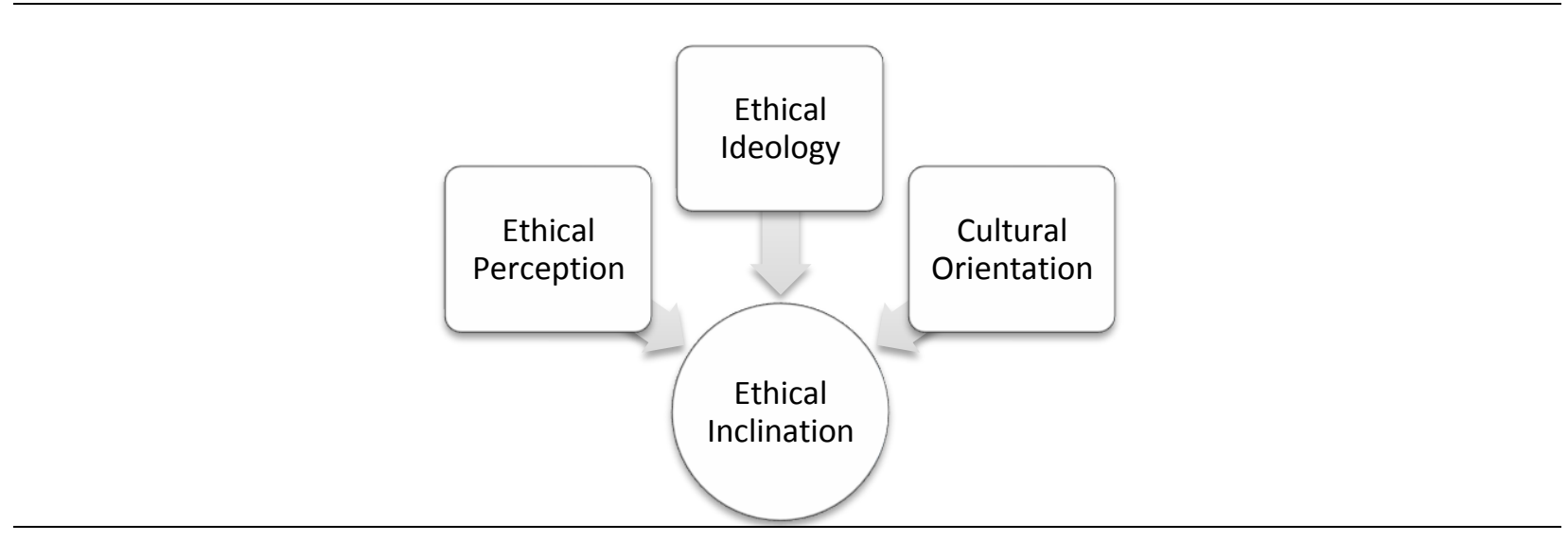

\section{METHODOLOGY}

\section{Sample}

The research sample is comprised of undergraduate marketing students at a university located in the northeastern part of the United States of America. All students participated voluntarily in the study. They were mostly marketing majors enrolled in upper level courses. All students have successfully completed an introductory marketing course, one business ethics course, and at least one philosophy course dealing in ethics and morality. 180 students completed a self-administered, self-report questionnaire. The average age of the respondents was 20.92 years. $53.9 \%$ of the students were female and $46.1 \%$ were male. All data were collected within a single time period.

\section{MEASURES}

Laczniak and Murphy (1993) define marketing ethics as "the systematic study of how moral standards are applied to marketing decisions, behaviors, and institutions." Vitell (1986) describes marketing ethics as "inquiry into the nature and grounds of moral judgments, standards, and rules of conduct relating to marketing decisions and marketing situations" (p. 4). Sparks and Hunt (1998) assert that these ethics are both personal and learned. Taking into account the need to understand the personal nature and grounds of moral judgment held by marketing students, measures were carefully chosen for their inherent focus on the individual.

\section{Ethical Ideology}

Ethical ideology was measured using the 20-item Ethical Position Questionnaire (Forsyth, 1980), which assesses an individual's general moral philosophy. Individuals may take up their own combinations of idealistic and relativistic ideologies. Hence, they are not necessarily divisible as either purely idealistic or relativistic. Ten items were used to measure idealism and relativism, both of which exhibited favorable psychometric properties: $\alpha=.839$ and $\alpha=.744$, respectively (Nunnally, 1978) (See Table 1).

\section{Cultural Orientation}

In light of this study's focus on individualized ethical ideologies and moral perceptions, it is appropriate and necessary to examine culture at the individual level. While Hofstede's framework has been adopted for crosscultural research at the national level, Donthu and Yoo (1998) identified an "ecological fallacy" in the inappropriate, yet popular practice of characterizing individuals based on their national citizenship or heritage. As a result, they developed a new scale for assessing how Hofstede's dimensions are manifest at the individual level. This revised 
approach then makes it reasonable to contemplate culture as "software of the individual's mind." Therefore, culture was assessed using items from Donthu and Yoo's (1998) scale of individual cultural orientation. This scale measures the individual-level equivalents for the five dimensions of national culture developed by Hofstede (1980, 1991), thus enabling this study's concentration on individualized ethics.

As noted above, this study focused on two dimensions of cultural orientation: power distance and collectivism. Power distance was measured with five items, and collectivism was measured with six items. All items were evaluated using a 5-point Likert-type scale with anchor of 1 (strongly disagree) to 5 (strongly agree). Both measures demonstrated satisfactory psychometric properties (Nunnally, 1978). Cronbach's alpha coefficients showed that the construct reliability for two dimensions were $\alpha=.768$ and $\alpha=.838$ for power distance and collectivism, respectively (See Table 1).

Table 1

Descriptive Statistics, Construct Reliabilities, and Correlations

\begin{tabular}{|c|c|c|c|c|c|c|c|c|c|}
\hline & & \multicolumn{2}{|c|}{ Scale Items } & \multicolumn{2}{|l|}{ Mean } & \multicolumn{2}{|c|}{ Std. Deviation } & \multicolumn{2}{|c|}{ Cronbach's $\alpha$} \\
\hline \multirow[t]{2}{*}{ Ethical Perception } & EP1 & 1 & & 7.69 & & 1.98 & & - & \\
\hline & EP2 & 1 & & 5.97 & & 2.16 & & - & \\
\hline \multirow[t]{2}{*}{ Ethical Inclination } & EI1 & 1 & & 2.17 & & 1.52 & & - & \\
\hline & EI2 & 1 & & 3.89 & & 1.91 & & - & \\
\hline Ethical Idealism & EPI & 10 & & 35.30 & & 5.64 & & .83 & \\
\hline Ethical Relativism & EPR & 10 & & 31.07 & & 4.96 & & .74 & \\
\hline Power Distance & POW & 5 & & 2.06 & & .59 & & .76 & \\
\hline \multirow[t]{2}{*}{ Collectivism } & COL & 6 & & 3.33 & & .70 & & .83 & \\
\hline & & EP1 & EP2 & EI1 & EI2 & EPI & EPR & POW & COL \\
\hline \multirow[t]{2}{*}{ Ethical Perception } & EP1 & - & & & & & & & \\
\hline & EP2 & $.457 * *$ & - & & & & & & \\
\hline \multirow[t]{2}{*}{ Ethical Inclination } & EI1 & $-.380 * *$ & $-.248 * *$ & - & & & & & \\
\hline & EI2 & -.077 & $-.500 * *$ & $.452 * *$ & - & & & & \\
\hline Ethical Idealism & EPI & $.300 * *$ & $.242 * *$ & -.045 & -.098 & - & & & \\
\hline Ethical Relativism & EPR & .087 & -.002 & $.188^{*}$ & $.196 * *$ & $.232 * *$ & - & & \\
\hline Power Distance & POW & -.079 & $.201 * *$ & $.321 * *$ & $.259 * *$ & -.032 & $.178^{*}$ & - & \\
\hline Collectivism & COL & $.368 * *$ & $.174 *$ & -.043 & .059 & $.280 * *$ & .120 & .020 & - \\
\hline
\end{tabular}

$* \mathrm{p}<.05, * * \mathrm{p}<.01$

\section{Marketing/Sales Scenarios}

Marketing students were presented with two scenarios drawn and vetted from existing research on business ethics. Each scenario involves a selling situation. Selling scenarios are appropriate because they involve direct contact between sellers and buyers. Furthermore, selling represents the typical entry level marketing position for most new marketing graduates (Murphy et al., 2005). Additionally, new salespersons must learn to balance the competing interests of customers and companies they serve. While attempting to manage this balance, they must be mindful of the financial, persuasive, and credibility aspects of their selling orientations, all of which may be scrutinized with ethical inquiry. Whether faced with simple or complex scenarios, individuals are guided by their own nature and grounding in perceiving and evaluating ethical features of situations Vitell (1986). Here, two scenarios are considered:

Scenario 1: Automobile Salesperson (Source: Reidenbach et al. 1991)

An automobile salesperson is told by a customer that a serious engine problem exists with their trade-in vehicle. Because the salesperson desires to make the sale, he does not inform the used car appraiser at the dealership, and the problem is never identified. 
Action: The salesperson closes the deal accepting the trade-in vehicle.

Scenario 2: Retail Sales (Source: Dornoff and Tankersley 1975)

A young man, recently hired as a salesperson for a local retail store, has been working very hard to favorably impress his boss with his selling ability. At times, this young man, anxious for an order, has been a little overeager. To get the order, he exaggerates the value of the item or withholds relevant information concerning the product he is trying to sell. No fraud or deceit is intended by his actions; he is simply overeager.

Action: The owner of the retail store is aware of this salesperson's actions but has done nothing to stop such practices.

\section{Ethical Perception and Inclination}

Ethical perception and inclination were measured with single-item questions. Following each of the above scenarios, students provided responses to two statements evaluated with a 7-point Likert-type scale, ranging from 'Strongly Disagree' to 'Strongly Agree'. The first statement related to ethical perception regarding the scenario: "This situation involves an ethical problem." The second statement pertained to ethical inclination, reflecting how likely marketing students would enact the same behavior depicted in the scenario: "I would act in the same manner as the salesman in this situation." Students were advised that the statements and responses had no correct or incorrect answers.

\section{RESULTS}

The stated research hypotheses were evaluated with multiple regression in SPSS 16. Two separate regressions were used to assess the impact of three sets of variables - ethical perception, ethical ideologies, and cultural orientation - on ethical evaluations for each of the marketing/sales scenarios presented above. The following mathematical equation reflects the regression model evaluated:

$$
\mathrm{EI}=\alpha+\beta_{1} \mathrm{EP}-\beta_{2} \mathrm{EPI}+\beta_{3} \mathrm{EPR}+\beta_{4} \mathrm{POW}-\beta_{5} \mathrm{COL}+\varepsilon
$$

EI $=$ Ethical Intention; EP = Ethical Perception; EPI = Ethical Idealism; EPR = Ethical Relativism; POW $=$ Power Distance; and COL $=$ Collectivism

Despite the morally charged nature of the survey instrument, bivariate and partial correlations revealed no significant biases imparted by social desirability on any of the research variables. A correlation analysis preceded the regression analysis (See Table 1).

With regards to Scenario 1 and Scenario 2, each regression analysis provides support for $\mathrm{H}_{1}$, which stated that ethical perceptions are negatively associated with less moral ethical inclinations. That is, marketing students who perceived ethical issues in the two scenarios would not be inclined to favor the immoral behavior depicted by the marketers. Hence, it can be asserted that individuals who keenly perceive an ethical dimension(s) within a given situation are more likely to reject, rather than adopt, expectedly immoral or harmful behaviors (see Table 2).

Next, $\mathrm{H}_{2}$, which postulated that ethical idealism would be negatively associated with less moral ethical inclinations, was not supported. Idealism exhibited the expected sign only for Scenario 2, but still rendered negligible impact across both scenarios. So, the degree of ethical idealism espoused by a marketing student would not serve as a significant predictor of her/his tendencies to eschew the kinds of action depicted in Scenario 1 or 2.

Concerning the role of ethical relativism, $\mathrm{H}_{3}$ proposed that marketing students who possess high ethical relativism would be more inclined to repeat the behavior depicted by the marketers in each scenario. As expected, $\mathrm{H}_{3}$ was supported, bolstering the notion that ethical relativism may lead marketing students to enact less ethical behaviors in certain situations. 
Table 2

Regression Analysis

$\begin{array}{lllll}\begin{array}{l}\text { Scenario 1: Misleading Appraiser } \\ \mathrm{R}^{2}=.264, \mathrm{~F}=12.494, \mathrm{p}<.000\end{array} & & & \\ \text { Variables } & & \text { beta } & \mathbf{t} & \mathbf{p} \\ & & & & \\ \text { Ethical Perception } & \text { EP1 } & -.409 & -5.679 & .000 \\ \text { Ethical Idealism } & \text { EPI } & .027 & .385 & .701 \\ \text { Ethical Relativism } & \text { EPR } & .162 & 2.375 & .019 \\ \text { Power Distance } & \text { POW } & .075 & 1.050 & .295 \\ \text { Collectivism } & \text { COL } & .259 & 3.890 & .000\end{array}$

Scenario 2: Eager Salesperson

$\mathrm{R}^{2}=.321, \mathrm{~F}=16.477, \mathrm{p}<.000$

$\begin{array}{lllll}\text { Variables } & & \text { beta } & \text { t } & \text { p } \\ \text { Ethical Perception } & \text { EP2 } & -.484 & -7.313 & .000 \\ \text { Ethical Idealism } & \text { EPI } & -.054 & -.790 & .431 \\ \text { Ethical Relativism } & \text { EPR } & .168 & 2.569 & .011 \\ \text { Power Distance } & \text { POW } & .135 & 2.059 & .041 \\ \text { Collectivism } & \text { COL } & .128 & 1.970 & .050\end{array}$

Both $\mathrm{H}_{4}$ and $\mathrm{H}_{5}$ postulated that a relationship exists between individual cultural orientation and ethical inclination among marketing students. Specifically, $\mathrm{H}_{4}$ stated that power distance would be positively associated with an inclination to adopt less ethical behaviors. As shown in the regressions, power distance yields a significant positive influence on ethical intentions across Scenario $1(\beta=.075, \mathrm{t}=1.050, \mathrm{p} \leq .295)$ and Scenario $2(\beta=.135$, $\mathrm{t}=2.059, \mathrm{p} \leq .041$ ), thus providing partial support for $\mathrm{H}_{4}$. Therefore, it can be stated with reservations that marketing students with cultural values leaning towards high power distance can be expected to repeat some of the unethical behaviors they are exposed to in business case scenarios or other formal education. Finally, $\mathrm{H}_{5}$ stated that collectivism would be negatively associated with an inclination towards less ethical behaviors. The regression analyses for Scenario $1(\beta=.259, \mathrm{t}=3.890, \mathrm{p} \leq .000)$ and Scenario $2(\beta=.128, \mathrm{t}=1.970, \mathrm{p} \leq .050)$ show that collectivism is a significant predictor of ethical inclination, but not with the expected sign. Therefore, $\mathrm{H}_{5}$ cannot be supported.

\section{CONCLUSION AND IMPLICATIONS}

Business schools, instructors, and authors have attempted to immerse business students in a programmatic system of ethics and morality education. Yet, debate persists about whether this education if necessary, is actually sufficient to training student attention towards discerning and reacting properly to ethical issues. This study provides a contribution to the debate and possible resolutions. As shown here, individually held cultural values and ethical ideologies influence the ethical inclinations of marketing students. These results suggest that business educators and managers should concentrate some of their efforts towards learning and challenging the individually held cultural values, ideologies, and inclinations of young marketers. Furthermore, taking into account that ethics is both personal and learned (Sparks and Hunt 1998), academic educators and corporate trainers may need to produce exercises that challenge students to discuss the meaning and significance of ethical relativism to the business enterprise. Yu and Zhang (2006) inquired whether acceptance of wrongdoing starts at the training ground for future managers. So, perhaps, these "challenge exercises" might allow educators and trainers to observe "in action" whether prospective marketing hires evaluate and react to ethical situations in ways that are consistent with an organization's overall mission. Given the increasing corporate and public sensitivities to ethics and social responsibility, it is also essential that marketing students experience such exercises and other opportunities to discover and reflect upon their own ethical inclinations.

\section{AUTHOR INFORMATION}

Brent Smith is Assistant Professor of Marketing in the Erivan K. Haub School of Business at Saint Joseph's University (Philadelphia, Pennsylvania). His teaching and research interests include international marketing, marketing strategy, and marketing ethics. 


\section{REFERENCES}

1. $\quad$ Bartels, R. 1967. A model for ethics in marketing. Journal of Marketing 31 (January): 20-26.

2. Borkowski, S.C. and Y.J. Urgas. 1998. Business students and ethics: A meta-analysis, Journal of Business Ethics 17 (August): 1117-27.

3. Brenkert, George G. 2008. Marketing ethics. Malden, MA: Blackwell Publishing.

4. Cohen, J. R., L.W. Pant, and D. J. Sharp. 1992. Cultural and socioeconomic constraints on international codes of ethics: Lessons from accounting. Journal of Business Ethics 11:687-700.

5. Donthu, N., and B. Yoo. 1998. Cultural influences on service quality expectations. Journal of Service Research 1 (November): 178-86.

6. Dornoff, Ronald. J. and Clint B. Tankersley. 1975. Perceptual differences in market transactions: A source of consumer frustration. Journal of Consumer Affairs 9: 97-103..

7. Ford, R. C., and. D. Richardson. 1994. Ethical decision making: A review of the empirical literature. Journal of Business Ethics 13:205-21.

8. Forsyth, D. R. 1980. A taxonomy of ethical ideologies. Journal of Personality and Social Psychology 39: 175-184.

9. Forsyth, D. R. 1992. Judging the morality of business practices: The influence of personal moral philosophies. Journal of Business Ethics, 11 (May): 461-70.

10. Greenman, F.E. and J.F. Sherman III. 1999. Business school ethics - An overlooked topic. Business and Society Review 104 (Summer): 171.

11. Hall, Edward T. 1966. The hidden dimension: Man's use of space in public and private. London: Bodley Head.

12. Hartman, Laura P. and Joseph Desjardins. 2008. Business ethics: Decision-making for personal integrity and social responsibility. New York: McGraw-Hill Irwin.

13. Hofstede, Geert. 1980. Culture's consequences: International differences in work-related values, Newbury Park: Sage Publications.

14. Hofstede, Geert. 1997. Culture and organizations: Software of the mind. New York: The McGraw Hill Companies, Inc.

15. Hofstede, Geert. 2001. Culture's consequence: Comparing values, behavior, institutions, and organizations across nations. Thousand Oaks: Sage.

16. House, Robert J., Paul J. Hanges, Mansour Javidan, Peter W. Dorfman, and Vipin Gupta 2004, Culture, Leadership, and Organizations: The GLOBE Study of 62 Societies, Sage Publications, Thousand Oaks, CA.

17. Hui, C.H. and H.C.Triandis. 1986. Individualism-collectivism: A study of cross-cultural researchers. Journal of Cross-Cultural Psychology 17: 225-48.

18. Laczniak, G.R. 1999. Distributive justice, catholic social teaching, and the moral responsibility of marketers. Journal of Public Policy \& Marketing 18 (Spring): 125-29.

19. Laczniak, Gene R. and Patrick E. Murphy. 1993. Ethical marketing decisions: The higher road. Boston: Allyn \& Bacon.

20. McCabe, D.L., K.D. Butterfield, and L.K. Trevino. 2006. Academic Dishonesty in Graduate Business Programs: Prevalence, Causes, and Proposed Action Academy of Management Learning \& Education, 5 (3): 294-305.

21. Murphy, Patrick, Gene R. Laczniak, Norman E. Bowie, and Thomas A. Klein. 2005. Ethical marketing. Upper Saddle River, NJ: Pearson Education, Inc.

22. Reidenbach, R. Eric, Donald P. Robin, and Lyndon Dawson. 1991. An application and extension of a multidimensional ethics scale to selected marketing practices and marketing groups. Journal of Academy of Marketing Science 19 (Spring): 83-92.

23. Robin, Donald P. and R. Eric Reidenbach. 1993. Searching for a place to stand: Toward a workable ethical philosophy for marketing. Journal of Public Policy and Marketing, 12 (Spring): 97-105.

24. Schwartz, S. H. 1992, "Universals in the Content and Structure of Values: Theoretical Advances and Empirical Tests in 20 Countries," in Zanna, M.P. (Ed.), Advances in Experimental Social Psychology, Academic Press, Inc., San Diego, pp. 1-65.

25. Schwartz, S.H. and W. Bilsky. 1987. Toward a psychological structure of human values. Journal of Personality and Social Psychology 53: 550-62. 
26. Shannon, J.R. and R.L. Berl. 1997. Are we teaching ethics in marketing? A survey of students' attitudes and perceptions. Journal of Business Ethics 16 (July) 1059-75.

27. Sparks, J.R. and S.D. Hunt. 1998. Marketing researcher ethical sensitivity: Conceptualization, measurement, and exploratory investigation. Journal of Marketing 62 (April): 92-109.

28. Vitell, S. J. 1986. Marketing ethics: Conceptual and empirical foundations of a positive theory of decision making in marketing situations having ethical content. Doctoral dissertation, Texas Tech University, Lubbock.

29. Vitell, S. J., S. L. Nwachukwu, and J. H. Barnes. 1993. The effects of culture on ethical decision-making: An application of Hofstede's typology. Journal of Business Ethics 12:753-60.

30. Wines, W.A. and N.K. Napier. 1992. Toward an understanding of cross-cultural ethics: A tentative model. Journal of Business Ethics 11: 831-41.

31. Yoo, Boonghee and Naveen Donthu. 2002. The effects of marketing education and individual cultural values on marketing ethics of students. Journal of Marketing Education 24 (August): 92-103.

32. Yu, Olivia and Lening Zhang. 2006. Does acceptance of corporate wrongdoing begin on the 'training ground' of professional managers? Journal of Criminal Justice 34: 185-194.

\section{$\underline{\text { NOTES }}$}

